\title{
Analisis Rekayasa Sub Sistem Penujang Pada Kegiatan UPBS Kedelai Di Lahan Kering (Studi Kasus di Desa Suo-Suo, Kecamatan Sumay Kabupaten Tebo Jambi)
}

\author{
Suharyon dan Yarda \\ Balai Pengkajian Teknologi Pertanian (BPTP) Jambi \\ Jl.Samarinda Paal V Kota Baru, Kota Jambi, Jambi 36129 \\ J1.Tentera Pelajar No.10 Cimanggu Bogor 16114 \\ Email: suharyonhariyon@mail.com
}

\begin{abstract}
ABSTRAK
Dalam upaya mengembangkan sistem usahatani di suatu wilayah diperlukan pendekatan hubungan antara kelompok tani dengan kelembagaan lain yang mendukung. Dengan terjalinnya kerja sama kelembagaan yang mantap, masalah yang dihadapi petani bisa diserahkan sekaligus diharapkan terjadi difusi teknologi melalui lembaga atau institusi terkait di daerah. Dengan memberdayakan kelembagaan yang mendukung adopsi teknologi yang diberikan kepada kelompok tani FSA (Farming System Analysis) dalam bentuk kerja sama akan membantu memecahkan masalah-masalah yang dihadapi petani. Berdasarkan pemikiran tersebut, maka perlu dilakukan kajian analisis rekayasa kelembagaan penunjang teknologi usahatani. Kegiatan ini dilaksanakan di desa Suo-Suo, Kecamatan Sumay Kabupaten Tebo dengan tujuan menemukan perlakuan/intervensi yang efektif dan meningkatkan pemberdayaan, serta kerja sama kelembagaan guna menjamin adopsi teknologi sistem usahatani lahan kering yang berkelanjutan. Pendekatan yang digunakan adalah SWOT ANALYSIS yaitu identifikasi kekuatan, kelemahan, peluang, dan ancaman. Metodologi yang digunakan dalam kegiatan ini dengan menerapkan metode Participatory Research Appraisal (PRA), untuk menggali masalah yang dihadapi oleh petani. Alternatif intervensi yaitu dibentuknya beberapa kelompok tani atau dapat disebut Gapoktan yang diberi nama Poktan Sukajaya, diskusi singkat tentang sistem usaha tani kedele, meneliti kebutuhan mendesak kelompok tani, dan menghubungkannya dengan lembaga pendukung. Bedasarkan hasil PRA maka permasalahan yang diperioritaskan adalah (1) jadwal pertemuan kelompok masih kurang, (2) jalan usahatani kelokasi masih jalan tanah, kalau datang hujan agak sedikit terganggu, (3), cuaca/iklim, (4) hama dan penyakit (hama kepik pada daun), dan (5) Modal. Tujuan menemukan perlakuan/intervensi yang efektif dan meningkatkan pemberdayaan, serta kerja sama kelembagaan guna menjamin adopsi teknologi sistem usahatani lahan kering yang berkelanjutan.
\end{abstract}

Kata kunci : sub sistem penunjang, lahan kering, UPBS kedelai

\section{PENDAHULUAN}

Suatu komunitas dapat dilihat sebagai sebuah komponen sistem sosial, dimana komponen-komponennya saling berhubungan secara fungsional. Antar kelompok tani dalam hamparan di lokasi FSA (Farming System Analysis) juga memiliki keterkaitan kelompok. Di samping itu, juga terdapat hubungan eksternal atau hubungan antara unsur-unsur internal dan eksternal. Dalam upaya pengembangan sistem penunjang usahatani di suatu wilayah, diperlukan pendekatan hubungan antara kelompok dengan kelembagaan lain yang mendukung (Anonim, 2010).

Berdasarkan hasil pengkajian sebelumnya kelembagaan yang diberdayakan adalah kelompok tani "Poktan Sukajaya desa Suo-Suo, Kecamatan Sumay Kabupaten Tebo". Dari hasil survei diperoleh informasi bahwa produktivitas kedelai sebesar $900 \mathrm{~kg} / \mathrm{ha}$, sekitar 10\% $15 \%$ tanaman kedelai pada lahan kering mudah terserang hama kepik hitam yang menyerang 
pada pagi hari, sehingga menyebabkan daun berlobang-lobang sehingga menyebabkan tanaman tidak berproduksi. Selain permasalahan hama kepik hitam juga dipengaruhi oleh cuaca atau iklim, pada budidaya kedelai sebagian petani masih ada yang menggunakan benih lokal, masih belum terjadwal pertemuan dengan anggota kelompok sehingga jadwal tanam dilaksanakan kurang serentak sehingga dapat menyebabkan peningkatan populasi hama, dan adanya keterbatasan penyediaan pupuk subsidi disamping kurang bersahabatnya cuaca pada saat petani melakukan aktifitas sehari-harinya (bertanam, menyemai, memupuk dan sebagainya) (hasil wawancara dengan ketua kelompok tani Bapak Senan, 2019).

Masyarakat Desa Suo-Suo, Kecamatan Sumay Kabupaten Tebo pada umumnya bermata pencaharian sebagai petani baik petani kebun maupun padi dan tanaman palawija lainnya. Masih ada ditemukan permasalahan yang dihadapi petani membutuhkan peningkatan penanganan dan pembinaan agar usahatani yang dilakukan menjadi lebih baik. Dalam hal ini, Balai Pengkajian Teknologi Pertanian (BPTP) Jambi berinisiatif melakukan upaya perbaikan melalui pengamatan pada kelompok tani saja dan penelusuran terhadap institusi sebagai pendukung proses adopsi teknologi dan pengembangan wilayah. Dengan terjalinnya kerja sama kelembagaan yang mantap, masalah yang dihadapi petani dapat diatasi sekaligus diharapkan terjadi proses difusi teknologi melalui lembaga tersebut. Dengan internalisasi teknologi petani, maka proses adopsi teknologi diharapkan bisa lebih cepat. Dengan memberdayakan kelembagaan yang mendukung adopsi teknologi kepada kelompok tani FSA khususnya dalam bentuk kerjasama, akan membantu memecahkan masalah-masalah yang dihadapi petani. Dengan demikian, tujuan pengkajian adalah menemukan intervensi efektif dan meningkatkan pemberdayaan, serta kerja sama kelembagaan guna menjamin adopsi teknologi sistem usahatani kedele di lahan kering yang berkelanjutan melalui identifikasi kekuatan, kelemahan, peluang, dan ancaman dengan pendekatan SWOT (Strenghs, Weaknesses, Opportunities, Threats) analisis. Tujuan menemukan perlakuan/intervensi yang efektif dan meningkatkan pemberdayaan, serta kerja sama kelembagaan guna menjamin adopsi teknologi sistem usahatani kedele pada lahan kering yang berkelanjutan (Anonim, 2012).

\section{METODOLOGI PENGKAJIAN}

\section{Pengertian dan Tahapan Kegiatan}

Kelembagaan yang dimaksud dalam pengkajian mencakup kelembagaan aparat desa, kelompok tani, lembaga adat, dan instansi pemerintah. Sedangkan institusi meliputi normanorma dan perilaku petani yang berlaku di wilayah setempat, misalnya aturan-aturan yang mengatur antara patron dan klien. Sesuai dengan tujuan pengkajian akan dilakukan tahapantahapan sebagai berikut (1) menerapkan metoda Participatory Research Appraisal (PRA) untuk menggali masalah yang dihadapi oleh petani, (2) setelah masalah disusun berdasarkan prioritas, maka dilakukan ujicoba bersama di petani sesuai dengan kemampuan petani, (3) mempelajari kebijakan yang dioperasionalkan oleh lembaga terkait, dan (4) menghubungi lembaga-lembaga terkait untuk mengemukakan masalah yang dihadapi petani.

\section{Kebutuhan Teknologi Petani}

Berdasarkan identifikasi, kebutuhan teknologi petani meliputi (1) penggunaan varietas unggul, (2) teknologi sistem usahatani (SUT) kedelai, (3) alat dan mesin pertanian untuk tanaman kedelai, (4) sarana produksi, (5) bimbingan teknis secara rutin, dan (6) penyuluhan. 
Peubah yang diamati adalah (1) masalah dan tantangan kelompok tani, (2) alternatif pemecahan masalah oleh kelompok tani, (3) frekuensi dan topik pertemuan antara kelompok tani dengan lembaga terkait, (4) bentuk kerja sama dengan lembaga terkait, (5) program aksi yang diterima dan ditolak, serta (6) keberhasilan program aksi.

\section{Diagram Kelembagaan (Venn)}

Diagram kelembagaan menunjukkan pandangan anggota masyarakat tentang lembaga dan organisasi lokal termasuk bagaimana hubungan masing-masing kelembagaan dan organisasi itu mempengaruhi kehidupan masyarakat di pedesaan. Diagram ditunjukkan dengan ukuran lingkaran berbeda-beda yang menunjukkan pentingnya suatu kelembagaan di pedesaan. Keterkaitan antar lembaga ditunjukkan dengan ada tidaknya kontak atau kerja sama dalam pengambilan keputusan atau adanya keanggotaan ganda. Lingkaran bersentuhan menunjukkan ada hubungan atau informasi tersampaikan antara lembaga/organisasi, sedangkan bila terdapat tumpang tindih berarti ada kerja sama dan keterkaitan atau keanggotaan ganda dalam pengambilan keputusan (Shawki,B.C. 1999, Jhon Dixon.A.G. 2001 dan Umarjono, 1992).

\section{HASIL DAN PEMBAHASAN}

\section{Karakteristik Desa Suo-Suo Kabupaten Tebo}

PRA dilakukan di Desa Suo-Suo, Kecamatan Sumay Kabupaten Tebo Provinsi Jambi yang merupakan salah satu sentra komoditas kedele dan palawija lainnya. Wilayah ini sebagian besar dihuni oleh penduduk asli Melayu (70\%), pendatang dari Jawa (20\%), Sumatera Barat (5\%) dan Sumatera Utra (5\%). Desa Suo-Suo terletak pada ketinggian \pm 58 150 meter dari permukaan laut dengan luas wilayah adalah 11.980 ha. Mata pencaharian utama penduduk adalah (1) bercocok tanam padi sawah, kedelai jenis varietas yang digunakan sebagian besar adalah varietas Anjasmoro, dan VUB, (2) bercocok tanam karet, kelapa sawit, dan pinang, (3) sebagian ada yang memelihara ternak seperti ayam buras, sapi dan kambing, (4) perikanan (mina padi, kolam, keramba dan UPR) dan (5) bercocok tanam palawija seperti kacang-kacangan, dan jagung. Untuk komoditas perkebunan, umumnya tanaman karet, sawit yang ada di Desa Suo-Suo yang merupakan salah satu komoditas unggulan disamping tanaman pangan padi sawah, kedele, jagung dengan kondisi tanaman cukup terawat bebas dari gangguan gulma lainnya.

Penggunaan lahan di Desa Suo-Suo, Kecamatan Sumay pada umumnya untuk lahan lebak rawa seluas (81 ha), tegalan (273 ha), lahan hutan rakyat seluas 1127 ha, lahan pekarangan (164 ha) . Pemanfaatan lahan di Desa Suo-Suo, Kecamatan Sumay secara umum untuk tanaman perkebunan seperti; tanaman kelapa (58 ha), karet (41 ha), sawit (62 ha), sayuran (22 ha), dan untuk tanaman buah-buahan (19 ha) (Programa Penyuluh Pertanian, Kecamatan Sumay, 2018).

\section{Profil Kelembagaan di Lokasi Pengkajian}

Kelompok tani sebagai kelembagaan petani di pedesaan pada dasarnya berfungsi sebagai wadah kerja sama, kelas belajar, sedangkan yang terkait dengan pengelolaan unit produksi belum berfungsi sebagaimana mestinya. Kelompok tani/Poktan Sukajaya di desa Suo-Suo, Kecamatan Sumay kemampuannya bervariasi meliputi kelas pemula, kelas madya, 
dan kelas lanjut. Kelompok tani yang telah terbentuk ini aktivitasnya masih kurang, karena frekuensi musyawarah/pertemuan kelompok tani masih rendah.

Koperasi unit desa (KUD) sekarang berubah menjadi Gabungan kelompok tani (Gapoktan) sesuai fungsinya sebagai pelayan masyarakat petani dalam penyediaan saprodi dan tempat simpan pinjam sangat pengaruh terhadap masyarakat berada dalam lingkaran desa. Keberadaan yang ada adalah Lembaga Pemberdayaan Masyarakat (LPM) yang berfungsi sebagai tempat diskusi kelompok dan tidak sama fungsinya seperti KUD. Dengan demikian, LPM ini seharusnya dapat dimanfaatkan untuk melayani kebutuhan masyarakat/petani sebagai wadah pembantu perekonomian di pedesaan. Adanya kios-kios saprodi yang menyediakan sarana produksi juga dirasakan masyarakat/petani sebagai suatu untuk mendapatkan benih bermutu dan pupuk. Kendala yang dihadapi petani adalah pengaruh cuaca atau iklim sehingga berpengaruh untuk pertumbuhan tanaman mereka, kekurangan modal untuk membeli kebutuhan sehari-harinya, dan kondisi seperti ini merupakan kendala dalam mengatasi permodalan petani terutama fasilitas kredit usahatani. Kelembagaan pendidikan yang tersedia di Desa Suo-suo Kecamatan Sumay yang dirasakan sangat besar peranannya, seperti: Sekolah taman kanak-kanak (TK) 1 buah, Sekolah Dasar (SD) 1 buah, mesjid 2 buah, Madrasah 1 buah, musholla 1 buah, pesantren 1 buah, dan pasar masarakat. Tersedianya mesjid dan musholla sebanyak 2 buah tersebut sangat besar peranannya menjalankan bagi umat muslim sebagai sarana dalam menjalankan peribadatannya.

\section{Rekayasa Kelembagaan}

Rekayasa kelembagaan adalah upaya yang harus dilakukan dalam rangka membentuk suatu organisasi yang sesuai dengan kebutuhan petani dalam melaksanakan sistem usahataninya. Hal yang penting adalah memfungsikan organisasi tersebut, sehingga keberadaan dan manfaatnya dapat dirasakan oleh setiap anggota petani sesuai dengan tujuan dan harapan anggotanya. Dengan demikian, rekayasa kelembagaan adalah membangun aspek fisik dan non fisik dari kelembagaan penunjang pembangunan pertanian di pedesaan. Keterkaitan antar kelembagaan di Desa Suo-suo digambarkan pada diagram Venn berikut (Gambar 1).

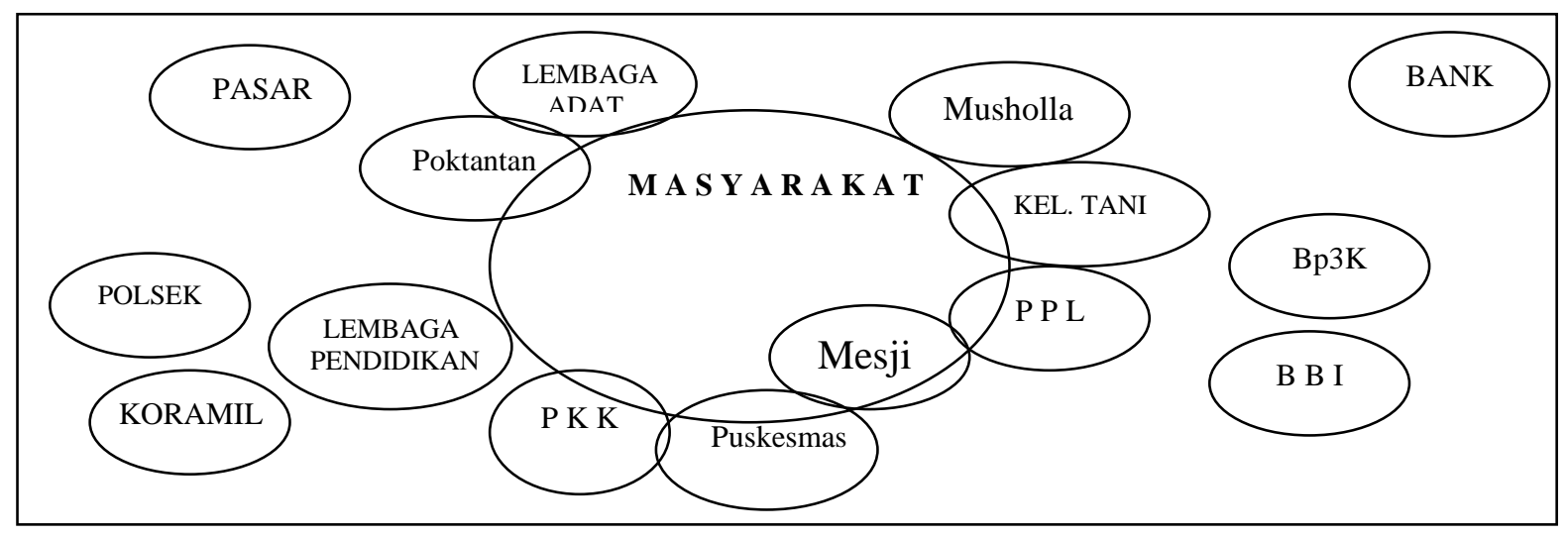

Gambar 1. Diagram Venn hubungan antara kelembagaan 


\section{Masalah dan Strategi Pemecahan}

Dari hasil PRA yang dilakukan, diidentifikasi berbagai masalah yang dihadapi masyarakat setempat yang sangat mempengaruhi sumber pendapatannya. Sumber pendapatan dari masyarakat setempat adalah dari bertani, berkebun karet, dan bertanam padi sawah, dan tanaman palawija, hortikultura lainnya. Hasil yang diperoleh dari panen karet masih rendah, karena petani tidak memakai bibit unggul dan tidak melakukan pemupukan. Masalah yang ditemukan adalah: kekompakan anggota kelompok, benih bermutu sering terlambat, pupuk subsidi, adanya hama dan penyakit akar putih yang sangat mempengaruhi pertumbuhan tanaman karet, begitu juga hama kutu daun yang dapat merusak pada daun tanaman kedele dan juga menyerang tanaman pangan di samping kendala rantai pemasaran. Pada tanaman kedele, permasalahan utama seperti yang dibahas sebelumnya yang dihadapi masyarakat/petani adalah serangan hama/kutu daun yang dapat menyerang pada daun tanaman, serta kekurangan modal (Tabel 1).

Tabel 1. Beberapa masalah usahatani Palawija, Pangan, Perkebunan, Peternakan dan Perikanan di Desa Suo-suoi, Kecamatan Sumay Kabupaten Tebo

\begin{tabular}{|c|c|c|c|c|c|c|c|}
\hline \multirow{2}{*}{ No } & \multirow{2}{*}{ Masalah } & \multicolumn{4}{|c|}{ Kelompok } & \multirow{2}{*}{ Jumlah } & \multirow{2}{*}{ Prioritas } \\
\hline & & I & II & III & IV & & \\
\hline 1 & Kekompakan anggota kelompok & 2 & 3 & 3 & 3 & 11 & I \\
\hline 2 & Benih bermutu sering terlambat & 2 & 2 & 3 & 2 & 9 & III \\
\hline 3 & Pupuk bersubsidi & 2 & 2 & 3 & 3 & 10 & IV \\
\hline 4 & $\begin{array}{l}\text { Hama tikus/keong mas serta jamur } \\
\text { akar putih, hama kutu daun pada } \\
\text { kedele }\end{array}$ & 2 & 2 & 3 & 2 & 9 & III \\
\hline 5 & Modal & 2 & 2 & 1 & 2 & 7 & V \\
\hline
\end{tabular}

Keterangan $: \mathrm{I}$ = sangat penting, II = penting, III = cukup penting, IV = agak penting, $\mathrm{V}=$ kurang

Dari lima permasalahan yang telah teridentifikasi, maka dapat diperioritaskan (1) kekompakan anggota kelompok masih kurang, (2) benih bermutu sering terlambat sehingga terganngu aktifitas petani , (3) masih kurang tersedianya pupuk bersubsidi, (4) adanya hama tikus/keong pada tanaman padi, dan hama kutu daun pada tanaman kedele, dan (5) kekurangan modal dapat menyebabkan kebutuhan sehari-hari bagi petani. Permasalahan yang ditemukan pada tanaman kedele adalah serangan hama kutu daun, sehingga harus dilakukan pengendalian secara terpadu oleh masyarakat Desa Suo-suo, Kecamatan Sumay. Di samping itu, petani belum banyak melakukan pengendalian secara terpadu dan kimiawi. Hal ini berdampak pada rendahnya hasil yang diperoleh. Oleh karena, itu disarankan kepada lembaga-lembaga penelitian yang relevan agar melakukan introduksi teknologi pengendalian hama tikus, dan kutu daun pada kedele baik secara bergotong royong, menggunakan musuh alami, dan secara kimiawi.

Permasalahan hama dan penyakit yang banyak dijumpai pada tanaman padi, kedele, karet adalah jamur akar putih, sedangkan teknologi perbenihan baik komoditas padi dan karet adalah petani belum bisa mendapatkan benih berkualitas dari instansi terkait. Di samping itu, petani juga belum banyak menangkarkan benih, sehingga sebagian besar benih yang 
digunakan adalah hasil tanaman sebelumnya atau turunan benih lokal dan belum menggunakan benih berkualitas. Dengan kehadiran Instansi Badan Litbaqng Pertanian dalam hal ini Balai Pengkajian Teknologi Pertanian (BPTP) akan dapat membantu dari sisi teknologi, baik menyediakan bibit bermutu, dan teknologi inovasi pertanian secara keseluruhan. penyediaan Dari segi pemasaran juga perlu diperbaiki karena berdampak terhadap hasil, padahal hasil teknologi yang dilakukan harus didukung oleh keberadaan pasar yang memadai (Aima, 2002, Bambang Irawa et al, 2005).

\section{KESIMPULAN}

Berdasarkan hasil PRA maka terdapat permasalahan yang dihadapi petani Desa SuoSuo, Kecamatan Sumay Kabupaten Tebo Provinsi Jambi berdasarkan prioritasnya, berturutturut adalah (1) masih kurangnya kekompakan anggotan kelompok, (2) benih bermutu sering terlambat sehingga aktifitas petani agak terganggu dalam menjalankan usahataninya, (3) pupuk subsidi belum banyak tersedia sehingga petani membeli pupuk non subsidi dengan harga yang cukup tinggi, (4) adanya serangan hama tikus dan keong pada tanaman padi, dan jamur akar putih pada tanaman karet, dan hama kutu daun pada tanaman kedele, (5) masih kurangnya sumber modal. Inovasi kelembagaan sangat diperlukan untuk membenahi semua kelembagaan dan seluruh komponen yang terlibat dalam kegiatan usahatani dan agribisnis agar dapat berfungsi dengan baik. Kelompok tani Desa Suo-Suo, Kecamatan Sumay Kabupaten Tebo dalam pelaksanaan inovasi Farming System Analysis (FSA) sangat responsif terlihat dari pertemuan dan wawancara langsung yang dilaksanakan selama kegiatan PRA baik secara kelompok maupun individu. Keputusan petani menjalankan usahatani di lahan kering, dan lahan kering ini tidak saja dipengaruhi faktor eksternal seperti keberadaan pasar input/output dan dukungan kelembagaan serta kebijakan pemerintah namun juga kondisi biofisik lahan usahatani yang kurang kondusif sehingga mempengaruhi keputusan petani.

\section{Daftar Pustaka}

Abdullah,Tj, Soewito,B.P, Ismail, dan Z,A, Simanullang, 2008. Status penelitian pemuliaan padi untuk memenuhi kebutuhan pangan masa depan, Balai Penelitian Tanaman Padi, Sukamandi.

Aima, HM. 2002. Pengembangan Karet Rakyat di Provinsi Jambi. Jurnal Ilmiah Univ. Batanghari Jambi. Vol. 2 No. 1 Pebruari, Hal $1-8$.

Anonim. 2018. Pragrama Penyuluh Pertanian. Kecamatan Sumay. Balai Penyuluh Pertanian. Dinas Tanaman Pangan Hortikultura dan Ketahanan Pangan Kabupaten Tebo.

Anonimous, 2014. Monografi desa Karya Bakti Kecamatan Rantau Rasau Tanjung Jabung Timur Provinsi Jambi.

Anonimous. 2009. Rencana Kegiatan Penyuluh Desa (RKPD). Badan Pelaksana Penyuluhan Pertanian Perikanan dan Kehutanan (BP4K). Desa Suo-suo, Kecamatan Sumay, Kabupaten Tebo.

Anoniomous. 2000. Materi temu kemitraan peneliti-penyuluh organisasi petani dan swasta di Kabupaten Merangin. Balai Pengkajian Teknologi Pertanian (BPTP) Jambi. Balai 
Besar Pengkajian dan Pengembangan Teknologi Pertanian. Badan Penelitian dan Pengembangan Pertanian, 4 - 5 Desember 2007.

Bambang Irawan, et al. 2005. Petunjuk Teknis PRA. Program Rintisan dan Akselerasi Pemasyarakatan Inovasi Teknologi Pertanian. Badan Litbang Pertanian. Departemen Pertanian.

Jhon Dixon and A.G. David Gibbon. 2001. Farming systems and poverty. Improving Farmers Livelihoods INA Changing World. Fao and World Bank Rome and Washington D.C. 2001.

Norman W. Simmonde. 1997. Farming system research a reviw. The Wold Bank Washington, D.C. U.S.A.

Peraturan Menteri Pertanian. 2011. Tata Hubungan Kerja Antar Kelembagaan Teknis, Penelitian, Dan Pengembangan, Dan Penyuluhan Pertanian Dalam Mendukung Peningkatan Produksi Beras Nasional (P2BN). NOMOR 45/Pementan/OT. $140 / 8 / 2011$.

Rencana Pembangunan Jangka Menengah Daerah (RPJMD) Kabupaten Tebo. Tahun 20112016.

Shawki,B,C, and Paul Siegel. 1999. Rural Diversification. Lessons from East Asia. The Wold Bank Washington,D.C. 1999.

Uamarjono, D.D. 1992. Penyempurnaan pendekatan tipologi sistem kelompok tani untuk mengidentifikasi tingkat partisipasi petani. Dalam majalah Perusahaan Gula.P3GI. Pasuruan th XXVIII Juni 1992 (1-2) 30-42. 